\title{
Editorial
}

\section{Biological exposure limits: the fetus and EEC politics}

Biological monitoring is "the measurement and assessment of agents or their metabolites either in tissues, secreta, excreta, expired air or any combination of these to evaluate exposure and health risk, compared to an appropriate reference," according to the EEC/NIOSH/OSHA seminar' convened in 1980. This applies to biological monitoring both in workers and the general public. From exposure response relationships exposure limits for external exposure can be derived such as TLVs, MACs, ADIs, or ambient air quality standards; for internal exposure biological exposure limits may also be derived.

Operational exposure limits should be established in a two step procedure: firstly, a group of experts (toxicologists, industrial physicians, hygienists) proposes health based recommended limits based solely on criteria of health protection; subsequently, the technological and socioeconomical constraints should be taken into account, resulting in a decision making process by all interested parties (employees, employers, representatives of the general public and government). Operational limits may even receive legal status as "standards." Both steps should be supported by full documentation which should also be available to those who actually run the risks (employees, general public). Therefore, the operational limits are ultimately the outcome of a health based evaluation of the toxicological data, followed by a policy decision making process.

Exposure limits should be directed to the groups most at risk. For exposure to inorganic lead, the fetus or young children, or both, ultimately determine the limits. The WHO recommended a health based maximal individual biological occupational exposure limit of $1.9 \mu \mathrm{mol} \mathrm{Pb} / \mathrm{l}(400 \mu \mathrm{g} \mathrm{Pb} / \mathrm{l})$ blood ( $\mathrm{PbB}$ ) for male workers and a PbB of $1.4 \mu \mathrm{mol} \mathrm{Pb} / 1$ $(300 \mu \mathrm{g} \mathrm{Pb} / \mathrm{l})$ for female workers of reproductive age, primarily to protect the fetus and the infant. ${ }^{2}$ Based on a proposal in $1974^{3}$ the EEC issued a directive in 1977 on the protection of the general public: in representative groups of the population the $\mathrm{PbB}$ should be $\leqslant 1.7 \mu \mathrm{mol} \mathrm{Pb} / \mathrm{l}(350 \mu \mathrm{g} \mathrm{Pb} / \mathrm{l})$ in $98 \%$ of the subjects examined, $\leqslant 1.4 \mu \mathrm{mol} \mathrm{Pb} / \mathrm{l}$ (300 $\mu \mathrm{g} \mathrm{Pb} / \mathrm{l})$ in $90 \%$, $\leqslant 0.96 \mu \mathrm{mol} \mathrm{Pb} / 1$ (200 $\mu \mathrm{g}$ $\mathrm{Pb} / \mathrm{l})$ in $50 \%$; at that time no distinction was made according to sex and age. This biological quality guide was applied in the 1979 and 1981 population studies in the nine member states. Because in the 1970s it became clear that the fetus, infant, and toddler might not be adequately protected by this biological quality guide, the Dutch government set a lower limit for young children: $98 \% \leqslant 1.4 \mu \mathrm{mol} \mathrm{Pb} / 1$ (300 $\mu \mathrm{g} \mathrm{Pb} / \mathrm{l}), 90 \% \leqslant 1 \cdot 2 \mu \mathrm{mol} \mathrm{Pb} / 1(250 \mu \mathrm{g} \mathrm{Pb} / \mathrm{l})$, and $50 \% \leqslant 0.96 \mu \mathrm{mol} \mathrm{Pb} / \mathrm{l}(200 \mu \mathrm{g} \mathrm{Pb} / \mathrm{l})$, although this proposal was not taken over by the EEC.

It should be acknowledged that the WHO occupational exposure limit aims to protect individual female workers and their offspring, whereas the EEC BQG serves primarily as an indirect assessment of the total exposure of the general public. In principle the WHO limit makes it possible for all female workers to have a $\mathrm{PbB}=1.4 \mu \mathrm{mol} \mathrm{Pb} / \mathrm{l}$ (300 $\mu \mathrm{g} \mathrm{Pb} / \mathrm{l})$, whereas the EEC directive stipulated that $90 \%$ of women and children should not exceed this level. Both the WHO proposal and the EEC directive were fully documented.

In Britain a new regulation and approved code was issued by the Health and Safety Commission: women of reproductive capacity with $\mathrm{PbB}$ $>1.9 \mu \mathrm{mol} \mathrm{Pb} / \mathrm{l}(400 \mu \mathrm{g} \mathrm{Pb} / \mathrm{l})$ should be suspended from work with lead; for male workers the limit was set at $3.8 \mu \mathrm{mol} \mathrm{Pb} / 1(800 \mu \mathrm{g} \mathrm{Pb} / \mathrm{l})$. The PbB concentration in umbilical blood approximates the level in maternal blood. Taking into account observations on the increased susceptibility of the developing nervous system, there is reason to lower the limit of $1.9 \mu \mathrm{mol} \mathrm{Pb} / \mathrm{l}(400 \mu \mathrm{g} \mathrm{Pb} / \mathrm{l})$ to at least $1.4 \mu \mathrm{mol}$ $\mathrm{Pb} / 1$ (300 $\mu \mathrm{g} \mathrm{Pb} / \mathrm{l})$.

Nevertheless, the maximal accepted British occupational exposure limit differed for male workers and for female workers of reproductive age, by sharp contrast with most other EEC countries. The Federal Republic of Germany recently set the limit for male workers at $3.4 \mu \mathrm{mol} \mathrm{Pb/l} \mathrm{(700} \mu \mathrm{g} \mathrm{Pb} / \mathrm{l})$ and for female workers of reproductive age at $2 \cdot 2 \mu \mathrm{mol} \mathrm{Pb} / \mathrm{l}(450 \mu \mathrm{g} \mathrm{Pb} / \mathrm{l})$.

In 1982 the EEC issued a directive for the protection of workers exposed to lead. The maximal individual $\mathrm{PbB}$ was set at $3.4 \mu \mathrm{mol} \mathrm{Pb} / \mathrm{l}(700 \mu \mathrm{g} \mathrm{Pb} / \mathrm{l})$ for all workers; even a PbB of $3.8 \mu \mathrm{mol} \mathrm{Pb} / 1$ $(800 \mu \mathrm{g} \mathrm{Pb} / \mathrm{l})$ is accepted if, at the same time, the ALAU $<17.0 \mu \mathrm{mol} / \mathrm{mmol}$ creat $(20 \mathrm{mg} / \mathrm{g}$ creat) or the ZZP $<20 \mu \mathrm{g} / \mathrm{g} \mathrm{HB}$, or the ALA-D $>6$ Europ units. The reproductive age of female workers is not taken into account, notwithstanding the original proposal of the Commission in 1978 to set a limit for $\mathrm{PbB}$ of $1.9 \mu \mathrm{mol} \mathrm{Pb} / \mathrm{l}(400 \mu \mathrm{g} \mathrm{Pb} / \mathrm{l})$ for this category 
of female workers. No official documentation of the recommended health based recommended limit and of the final operational limit has been published. Because of this EEC directive it has become difficult, although not forbidden, for member states to establish different oocupational exposure limits for male workers and female workers of reproductive age because of the impact on production costs: the EEC is first of all an economic community. The final directive is apparently the outcome of political negotiations; the basis for the decision is not documented and not fully explained to those who actually run the risk-working mothers and their offspring.

The unborn child of Mary Anne (Marianne, Maria, etc), occupationally exposed to lead, is permitted to run a risk of brain dysfunction, whereas the PbB-level of the fetus of her twin sister Anne (Anna, etc) who is not gainfully employed, should not exceed $1.7 \mu \mathrm{mol} \mathrm{Pb} / \mathrm{l}(350 \mu \mathrm{g} \mathrm{Pb} / \mathrm{l})$. In most countries it is forbidden for young children to visit the production departments because of the risk to their health. Why should the fetus be permitted to spend eight hours a day on the factory floor? Did the Council of Ministers in 1982 forget what they had decided in 1977? Why did the Council set different biological limits for the occupationally and the non-occupationally exposed fetus? $\mathrm{He} /$ she will never know, because the decision is not documented. The
Council of Ministers cannot state that it was unacquainted with the particular health risk to the fetus or the young child because it rejected a proposal which tried to take this risk into account.

This topic has wider implications than exposure to inorganic lead. It is only in the past decade that occupational health has begun to consider, not only adverse effects on the workers themselves, but also the prevention of reproductive risks, and this has become a criterion for TLVs and MACs. Although this is still terra incognita, on which even "angels fear to tread," let alone politiciaris, the reproductive risks and non-risks will gradually be established. This will ultimately have to lead to a drastic reappraisal of at least some TLVs and MACs and of biological occupational exposure limits.

R L ZIELHUIS Coronel Laboratory, University of Amsterdam, The Netherlands.

\footnotetext{
References

' Berlin A, Yodaiken RE, Henman BA, eds. Assessment of toxic agents at the workplace; roles of ambient and biological monitoring. Boston: Nijhof Publishing Co, 1984.

${ }^{2}$ World Health Organisation. Recommended health-based limits in occupaional exposure to heavy metals. Geneva: WHO, 1980. (Technical report series 647.)

${ }^{3}$ Zielhuis RL. Biological quality guide for inorganic lead. Int Arch Arbeitsmedo 1974;32:103-27.
} 